Journal of Engineering Sciences, Assiut University, Vol. 36, No. 2, pp. 461-469, March 2008

\title{
DETERMINATION OF PENETRATION RATE WHEN USING VIBRATION IN DRILLING OIL WELLS
}

\author{
Salameh Sawalha \\ Department of Mechanical Engineering Faculty of Engineering \\ Technology Marka,P .O.Box15008,11134 Amman Jordan \\ e-mail: Sawalha Salameh 80 @yahoo.com
}

(Received December 26, 2007 Accepted January 17, 2008)

The subject of oil as a source of energy occupies the main priority all over the world. Facts and statistics indicate that the average consumption of oil product exhausts half the world oil reserve in the last 150 years. The consumption average reaches 1300 billion barrel yearly.

In the beginning of the nineteenth century exploring and getting the oil was not a main challenge as it is now.

Since the main goal is still finding new oil traps even at deep depths where it reaches sometimes thousands of meters. This requires developing the well drilling techniques and huge equipments to increase the rate of penetration and decrease the digging cost.

In the last years, the efforts of professionals and those who are concerned in oil industry concentrate mainly in digging bit. While increasing the drills efficiency through developing the classic ways of drilling (the most popular all over the world is rotary drilling method) may be the most suitable way to achieve the mentioned goals.

This paper represents the results of practical study to determine the penetration rate using vibration. A group of cement samples with various compressive strengths were deducted. The results show that the penetration rate for these samples is higher than the values achieved by the rotary drilling method.

Also the study shows that we can achieve a good penetration rate (more than $15 \mathrm{~m} / \mathrm{h}$ ) with low level frequency.

KEYWORDS: oil wells, bit, rotary drilling method, penetration rate.

\section{INTRODUCTION}

Oil as a main source of energy still occupies the most important issue for the decision makers all over the word. Because of the increase in demand and the accelerated depletion and consequently the unusual high prices, the world becomes under high level of tension.

Studies show that the world market needs of oil reaches the highest levels (1300) billion barrel yearly. Also the consumption rate exhausted half of the world oil reserve in the last 150 years.[1]

From that comes the importance and necessity to develop the well drilling techniques and huge equipments. 
This paper represents a differ thinking in the mechanisms of wells drilling to increase the ability to reach more depths where the oil is collected since the world reserve has been changed in the light of exploring oil at the most depths we can reach.

\section{BRIEF REVIEW}

Ways of drilling through the earth have varied and developed since the first well drilled in Pennsylvania by the colonel Edwin Drake in the year 1860 using churn method. This method remains used until rig rotary drilling method appears in France in the beginning of the twentieth century. [2,3]

Rotary method depends on putting the bit at the end of a digging column with a rotation motion from equipments lies at the top of the well. [4].

When the depth is equal one drilling pipe length (usually $6 \mathrm{~m}$ ), the drilling process must stop to add a new drilling pipe. This process repeated until reaching the projected depth of well [5]

Although this method is efficient, the time loosed is very high because of the need to replace the bit at any depth you reach which requires pulling the drilling column (fig.1).

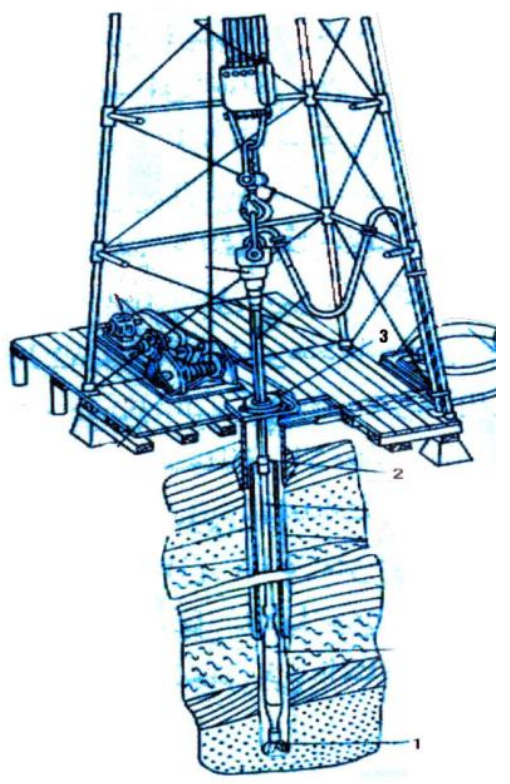

Fig.1: Diagram of a plant for rotary drilling 1-Bit 2- Drilling column 3-Drill motor rotor

As wells drilling increased all over the world the use of drilling equipment increased (21\% was the increase in drilled wells in the year 2005 than that in 2002) which means the used rigs will increase also. i.e. (the United States used 1250 rigs) [6, 7]. The number of drilled wells all over the world in the year 2005, are listed in table 1[6]. 
Table 1: drilled well all over the world in the year 2005

\begin{tabular}{|l|cc|c|}
\hline \multirow{2}{*}{ Country or continent } & \multicolumn{2}{|c|}{ Number of drilled wells } & Increase percentage \\
& 2004 & 2005 & in 2005 than 2004 \\
\hline United states of America & 34963 & 39958 & 12.5 \\
\hline North America & 22691 & 23810 & 4.7 \\
\hline South America & 557 & 624 & 10.8 \\
\hline Africa & 1104 & 1179 & 6.4 \\
\hline Middle east & 163 & 175 & 6.8 \\
\hline Far east & 1255 & 1256 & 0.1 \\
\hline South pacific & 294 & 299 & 1.7 \\
\hline
\end{tabular}

Figures in the table indicate the need of continuously developing oil industry to be suited with the increasing in number of drilled wells all over the world which need to develop drilling techniques and their equipments. All that is to respond at the increasing in oil demand.

But drilling ways seem to be not in the agenda of most of the oil companies since the rotary drilling method still the most dependent way, regardless of its foibles which agreed upon all those who are working in well drilling.

Here appears a question: can we drill wells by vibration? If it is possible, how can we supply the frequency needed to fragment the rocks? What are the equipments needed for these purposes? What if we look at the rig from another point of view (fig.2) so that the bit could be fixed with loads and transfer the vibration for it through cable or any device from equipments lies at the top of the well.

Mathematically we can express this system by equation:

$\mathrm{Fg}=\mathrm{F}_{\mathrm{r}}+\mathrm{mX}^{\prime \prime}+\mathrm{cX}+\mathrm{kX}$

Where:

Fg: force generated from power supply.

Fr: force affects the rocks.

m: mass of the bit.

$\mathrm{X}$ : amplitude (penetration)

$\mathrm{X}^{\prime}$ : velocity.

$\mathrm{X}^{\prime \prime}$ : acceleration.

$\mathrm{C}$ : viscous damping coefficient.

$\mathrm{K}$ : elasticity constant.

\section{EXPERIMENTAL PROGRAM}

To determine the frequency needed to destroy the rocks, penetration rate for cement samples was calculated using special device designed for this purpose.

This device (fig.3) contains non- centrically disc fixed on electrical motor with different frequency to give forced displacement transferred to the bit through the rod.

The experiment was done according to the following:

1. Standard cement samples (Fig.4) with dimensions in $\mathrm{mm}(50,50,50)$

2. Compressive strength of cement samples, 15, 20 and $30 \mathrm{Mpa}$. 
3. Dimension of bit according to the results achieved by prof. L. churner. The diameter of the bit must exceed 6.7 times the diameter of the rocks grains. Then the diameter of the bit must be not less than 1.6 to $3 \mathrm{~mm}$. this depends at the type of the rocks.[8]

4. The penetration rate $(\mathrm{m} / \mathrm{s})$ was used to express the efficiency of drilling by determining the mass of displaced cement from the sample in a time unit.

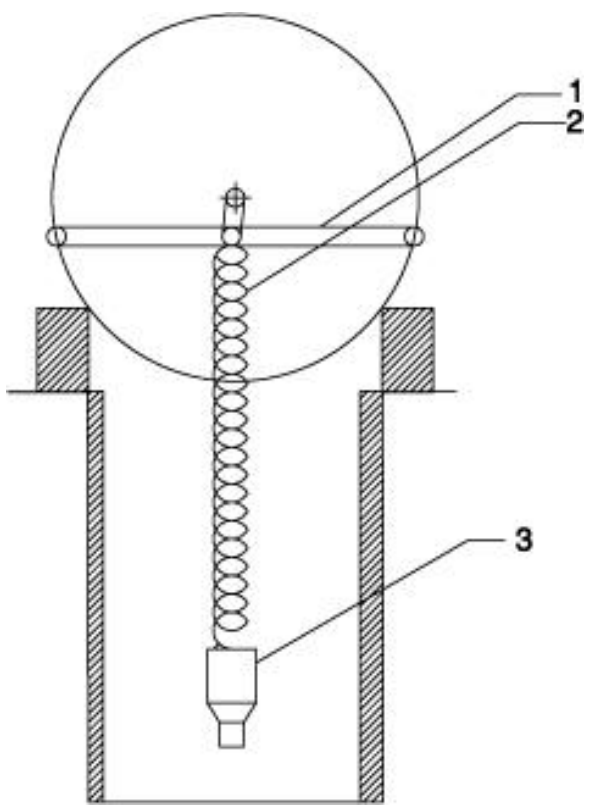

Fig.2: vibration drilling system

1- Electrical motor 2- Elasticity column 3- Drilling bit

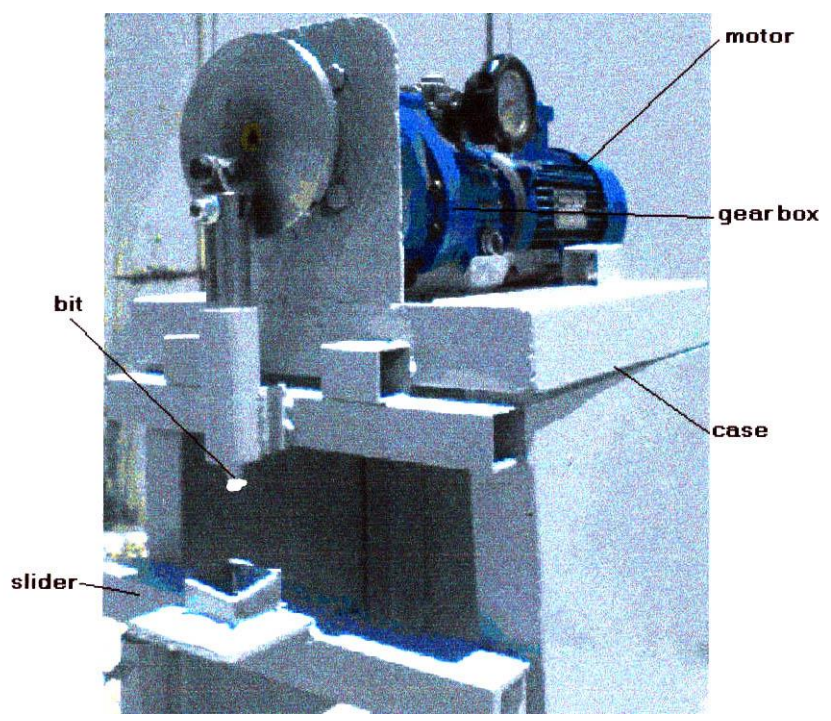

Fig.3: Vibration drilling device 


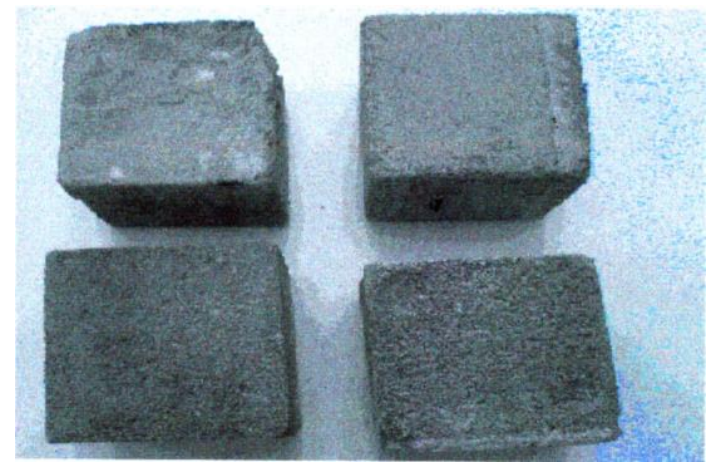

Fig.4: Cement samples

\section{RESULT AND DISCUSSIONS}

\section{Theoretical analysis}

Equation (1) was solved by Laplace transformations. It was found that:

$\mathrm{X}(\mathrm{S})=\left(\mathrm{F}_{\mathrm{g}}-\mathrm{F}_{\mathrm{r}}\right) /\left[\mathrm{S}\left(\mathrm{mS}^{2}+\mathrm{cS}+\mathrm{k}\right)\right]$

By substitution of the values used in designing the device $\left(\mathrm{F}_{\mathrm{g}}=237 \mathrm{~N} ; \mathrm{F}_{\mathrm{r}}=\right.$ $127 \mathrm{~N} ; \mathrm{m}=1.07 \mathrm{~kg} ; \mathrm{C}=5 \mathrm{~N} . \mathrm{sec} / \mathrm{m} ; \mathrm{K}=8160 \mathrm{~N} / \mathrm{m}$ ) In equation (2) we find that:

$X(S)=110 /\left(1.07 S^{3}+5 S^{2}+8160 S\right)$

Where: $\mathrm{X}(\mathrm{S})$ - transfer function

From equation (3) we can get the response of the system as displacement function of time (Fig. 5).

Figure 5 shows that the investigated amplitude of vibration is good to penetrate the rocks (about $3 \mathrm{~mm}$ )

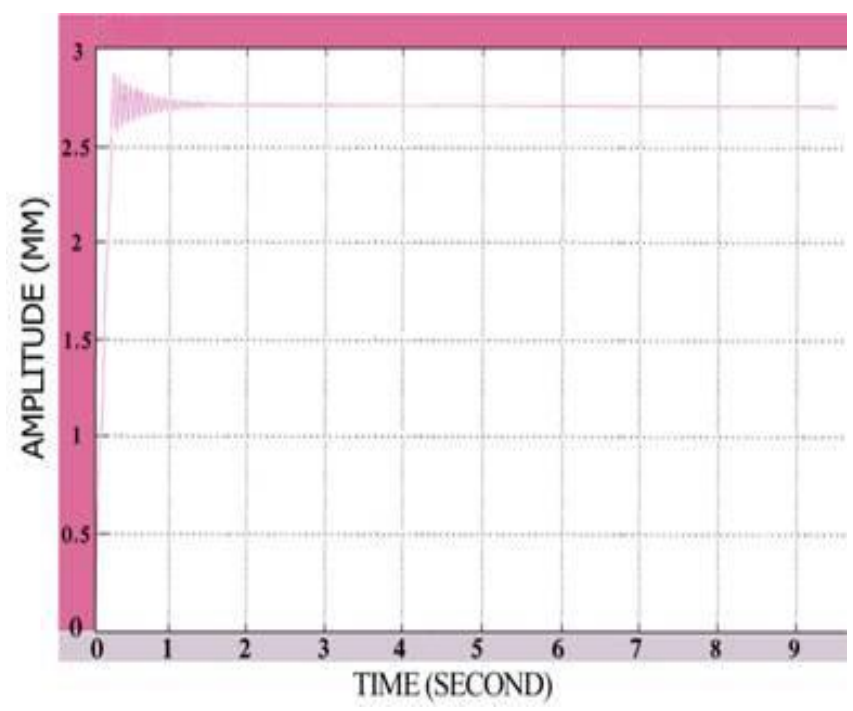

Fig.5: The response of the system 


\section{EXPERIMENT RESULTS}

Tables 2, 3, 4 and 5 show the displaced masses from cement samples in one minute at various frequencies.

Table 2: cement sample with ultimate strength $15 \mathrm{Mpa}$ (bit diameter $=3 \mathrm{~mm}$ )

\begin{tabular}{|c|c|c|}
\hline Frequency rad/s & Displaced mass gram/min & Penetration rate $\mathrm{m} / \mathrm{h}$ \\
\hline 10.57 & 9 & 30.51 \\
\hline 14.13 & 11 & 36.64 \\
\hline 15.7 & 12.5 & 44.30 \\
\hline 17.27 & 14.9 & 49.22 \\
\hline 20.9 & 15.8 & 53.91 \\
\hline
\end{tabular}

Table 3: cement sample with ultimate strength $20 \mathrm{Mpa}$ (bit diameter $=3 \mathrm{~mm}$ )

\begin{tabular}{|c|c|c|}
\hline Frequency rad/sec & Displaced mass gram/min & Penetration rate $\mathrm{m} / \mathrm{h}$ \\
\hline 10.99 & 7.2 & 24.41 \\
\hline 14.3 & 9 & 30.51 \\
\hline 16.43 & 11.1 & 37.63 \\
\hline 18.11 & 13.2 & 44.75 \\
\hline 20.9 & 14.8 & 48.85 \\
\hline
\end{tabular}

Table 4: cement sample with ultimate strength $30 \mathrm{Mpa}$ (bit diameter $=3 \mathrm{~mm}$ )

\begin{tabular}{|c|c|c|}
\hline Frequency rad/sec & Displaced mass gram/min & Penetration rate $\mathrm{m} / \mathrm{h}$ \\
\hline 10.99 & 5.4 & 17.8 \\
\hline 14.33 & 7.2 & 23.9 \\
\hline 15.18 & 9.6 & 33.5 \\
\hline 18.31 & 11.7 & 40.68 \\
\hline 20.9 & 12.6 & 42.71 \\
\hline
\end{tabular}

Table 5: cement sample with ultimate strength $30 \mathrm{Mpa}$ (bit diameter $=2.5 \mathrm{~mm}$ )

\begin{tabular}{|c|c|c|}
\hline Frequency rad/sec & Displaced mass gram/min & Penetration rate $\mathrm{m} / \mathrm{h}$ \\
\hline 10.99 & 8.1 & 39.5 \\
\hline 13.61 & 9.9 & 48.3 \\
\hline 16.22 & 12 & 58.5 \\
\hline 18.42 & 14.7 & 71.7 \\
\hline 21.25 & 15.6 & 76.1 \\
\hline
\end{tabular}




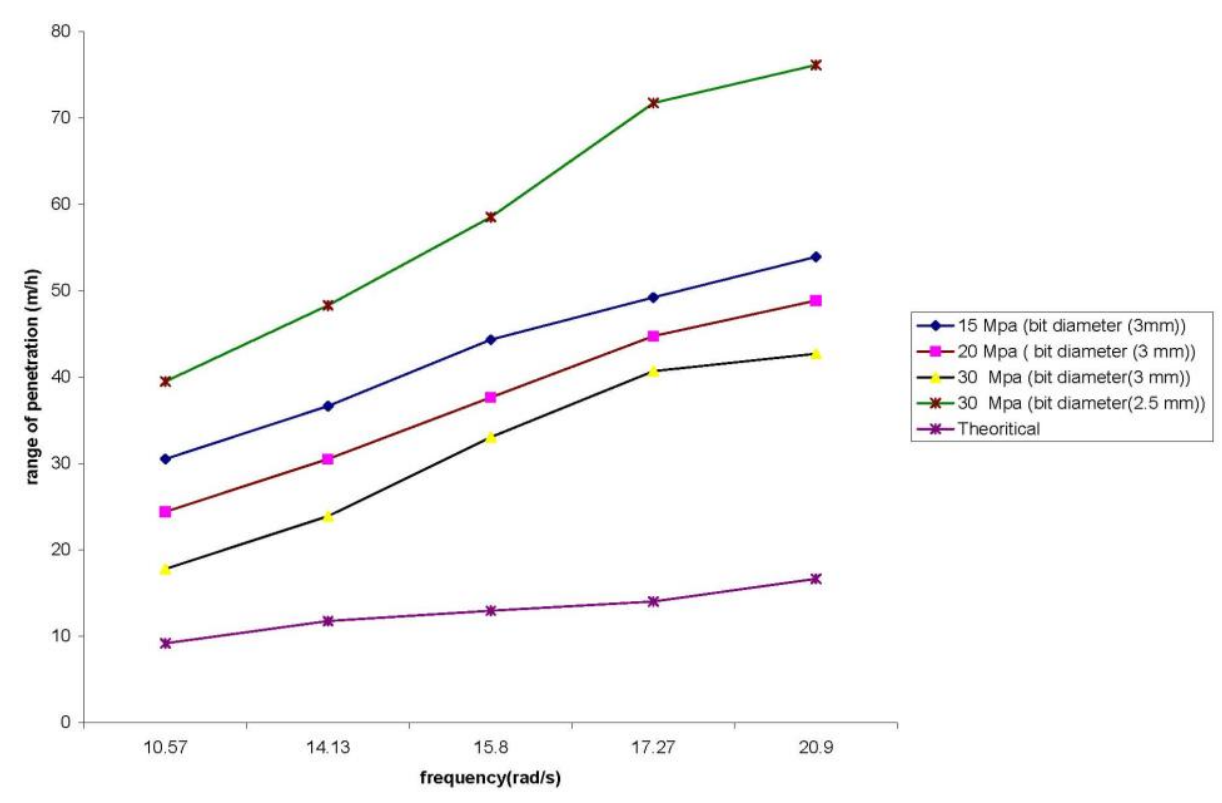

Fig (6): The relation between penetration rate and frequency.

\section{CONCLUSIONS}

1- When using the vibrations to fragment the rocks layers, the penetration rate is too higher than that in rotary drilling method $(15 \mathrm{~m} / \mathrm{hr}[8])$.

2- When comparing the penetration rate for the cement sample of compressive strength closed to marble strength, we find that the increase of penetration rate for the cement sample was more than $50 \%$.

3- Changing the diameter of the bit affects the penetration rate. It was observed that at bit diameter of $2.5 \mathrm{~mm}$ the penetration rate increases about $30 \%$ than it is for the bit with diameter $3 \mathrm{~mm}$.

4- The relation that controls the penetration rate is a linear one. But it begins to deviate at the high frequencies values (above $17 \mathrm{rad} / \mathrm{sec}$ ) because the contact time becomes less between the bit and the grain.

5- Drilling by vibration may be used at low frequencies and get higher penetration rate that it is in the case of rotary digging rig. At the same time supplying low frequency does not make any complexes for the digging process and the equipments used.

\section{REFERENCES}

1. Al -Jazerah T.V "Petroleum accelerated depletion", documentary, part one, $19 / 9 / 2007$. 
2. Lone star securities Inc.”Drilling Oil Wells",ch.4, www.lonestarsecurities.com, dated19/9/2007

3. Brantly J.E . "History of oil well drilling”, gulf publishing company ,2001.

4. Michael J. Economides, Larry T. Watters, Shari Dounn -Norman "Petroleum Well Construction" John Wiley and sons, 1998.

5. Adam T. Bourgoyne "Applied drilling engineering", society of petroleum engineers, 1986.

6. World Oil Magazine" All we need is more rigs and crews", Vol. 227, No 2, February 2006, www. worldoil.com

7. World Oil Magazine" Drilling activity surge will lead to record year", vol. 226 No 2, February 2005, www. worldoil.com

8. William C. Lyons, Gary J. Plisga "Standard hand book of petroleum and natural gas", second edition ,gulf professional publishing,2004.

\section{تحديد معدلات الاخترلق عند استخام التردد لحفر آبار النفط}

يحتل موضوع النفط كمصدر أساسي للطاقة أولوية قصوى على الصعيد العالمي, حيث تثشير الحقائق

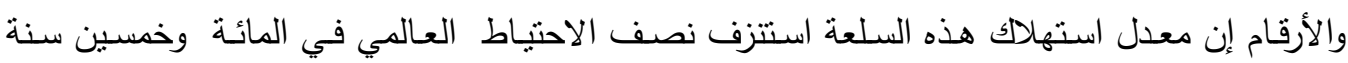
الأخيرة ليتجاوز 1300 مليار برميل سنويا.

في بداية القرن التاسع عشر لم تكن مسالة استكثاف واستخراج النفط من أعماق الأرض نتكل تحديا

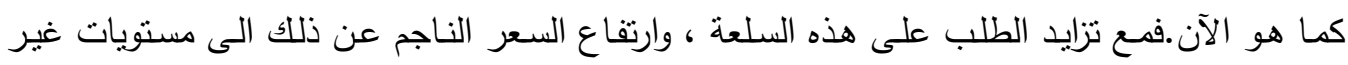

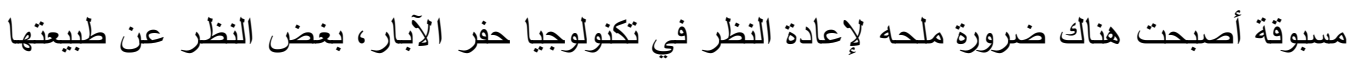

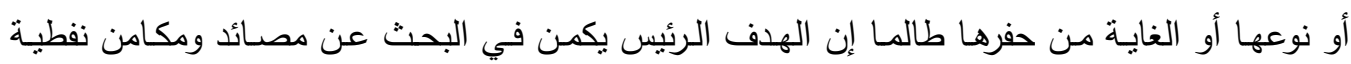
جديدة اغلبها يتواجد على أعماق كبيرة (تصل في بعض الأحيان إلى آلاف الأمتار). وهذا بدوره ينطلب

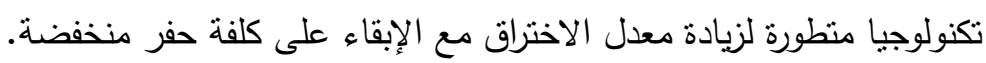

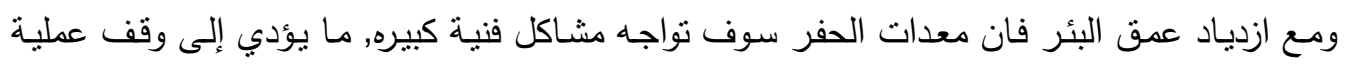

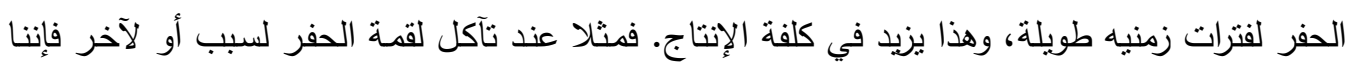

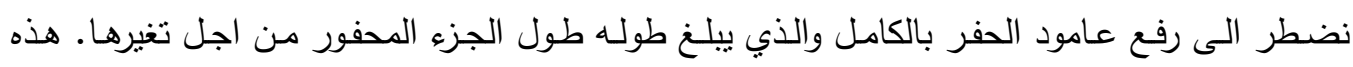
العملية تنطلب نوقفات زمنيه طويلة حسب طول العمق المحفور من البئر .

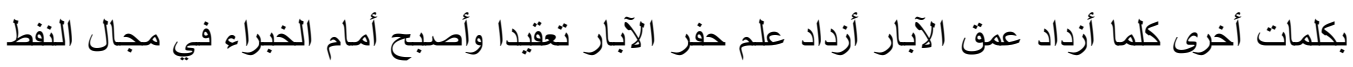

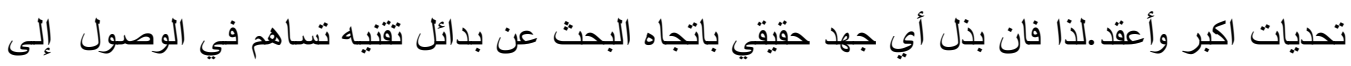
أعماق طبقات الأرض بسرعة وكلفة اقل يعتبر انجازا مهما كان بسيطا. 
وقـ انصـب جهـد الخبـراء والمعنيـين بصـناعة الـنفط في السـنوات الأخيـرة على تحسـين المـواد المستخدمة في صناعة لقم الحفر لإطالة عمرها، علما أن زيادة فاعلية الحفارات ورفع كفاءة أجزائها من خلال إعادة النظر في طرق الحفر الكلاسيكية قد نشكل الحل الأنثل لتطوير الصناعات النفطية. تستعرض هذه الورقة النتائج العملية لدراسة أجريت بهدف تحديد معدل الاختراق بواسطة الذبذبات، حيث

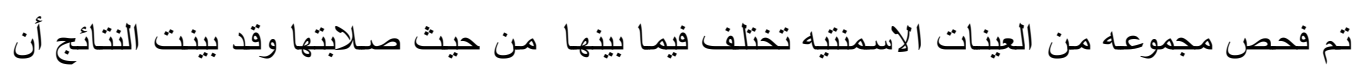
معدل الاختراق لهذه العينات أعلى من القيم النظرية التي يمكن تحقيقها عند حفر الآبار بالطريقة الرحويه (أكثر طرق الحفر الكلاسيكية انتشارا) وبزيادة بلغت 50\% وأكثر عن عينه صخريه لها نفس الصلابة. كما بينت الدراسـة إمكانيـة تحقيق معدل اختراق جيد (أكثر من 15 م/س) بتردد قليل (لا يتعدى 6.5 راديان/ث) ،الذي لا يشكل تأمينه صعوبة تقنيه كبيره. 